\title{
Reversed-Phase HPLC Analysis of Steviol Glycosides Isolated from Stevia rebaudiana Bertoni
}

\author{
Venkata Sai Prakash Chaturvedula*, Julian Zamora \\ Natural Products Research Group, Wisdom Natural Brands, Gilbert, USA \\ Email: ${ }^{\text {sprakash@wisdomnaturalbrands.com }}$
}

Received 3 July 2014; revised 4 August 2014; accepted 12 August 2014

Copyright (C) 2014 by authors and Scientific Research Publishing Inc.

This work is licensed under the Creative Commons Attribution International License (CC BY). http://creativecommons.org/licenses/by/4.0/

(c) (i) Open Access

\begin{abstract}
High Performance Liquid Chromatography (HPLC) experiments have been performed on nine steviol glycosides namely rebaudioside $A$, steviolbioside, stevioside, rubusoside, rebaudioside $B$, rebaudioside $C$, rebaudioside $D$, rebaudioside $F$, and dulcoside $A$ isolated from the leaves of Stevia rebaudiana using Reversed-Phase (RP) column. Using RP-HPLC method, the individual retention times for nine naturally occurring ent-kaurane diterpene glycosides of $S$. rebaudiana reported in JECFA have been determined at four different temperatures: $20^{\circ} \mathrm{C}, 40^{\circ} \mathrm{C}, 60^{\circ} \mathrm{C}$, and $79^{\circ} \mathrm{C}$. Also, calculated the relative retention times of the eight steviol glycosides steviolbioside, stevioside, rubusoside, rebaudioside $B$, rebaudioside $C$, rebaudioside $D$, rebaudioside $F$, and dulcoside $A$ against the major steviol glycoside rebaudioside A. HPLC results suggested that temperatures $40^{\circ} \mathrm{C}$ and $60^{\circ} \mathrm{C}$ would be ideal conditions for better separation of steviol glycosides.
\end{abstract}

\section{Keywords}

Stevia rebaudiana, Asteraceae, Diterpene Glycosides, Reversed-Phase HPLC Analysis, Retention and Relative Retention Times

\section{Introduction}

Recent interest of food and beverage industry has driven their focus towards natural high-potency sweeteners due to the increasing awareness of obesity problem and the health impacts associated with certain artificial sweeteners. Hence many soft drink manufacturers are trying to reduce calories by introducing natural non-caloric sweeteners into their systems. Stevia rebaudiana Bertoni, a perennial shrub belonging to the family of Astera-

*Corresponding author.

How to cite this paper: Chaturvedula, V.S.P. and Zamora, J. (2014) Reversed-Phase HPLC Analysis of Steviol Glycosides Isolated from Stevia rebaudiana Bertoni. Food and Nutrition Sciences, 5, 1711-1716.

http://dx.doi.org/10.4236/fns.2014.517184 
ceae (Compositae) is native to Paraguay and Brazil, but now is grown commercially in a number of countries, particularly in Japan, Taiwan, Korea, Thailand and Indonesia [1] [2]. Extracts of the leaves of S. rebaudiana have been used for decades to sweeten food and beverages in Japan, South America and China is one such example for the source of natural high potency sweeteners. The major constituents in the leaves of S. rebaudiana are the potently sweet glycosides namely stevioside, and rebaudiosides A; which are glycosides of the diterpene ent-13-hydroxykaur-16-en-19-oic acid and also known as steviol [3] [4]. Stevioside tastes about 150 - 250 times sweeter than sucrose, whereas rebaudioside A tastes about 200 - 300 times sweeter than sucrose. Both are noncaloric. These compounds are also known as stevia sweeteners.

As a part of our research related to the discovery of natural sweeteners and sweetener enhancers as well as developing analytical methods to identify and separate them, we are herewith describing a qualitative HPLC method for the nine steviol glycosides reported in Joint FAO/WHO Expert Committee on Food Additives (JECFA) 2010 monograph [5] namely rebaudioside A (1), steviolbioside (2), stevioside (3), rubusoside (4), rebaudioside B (5), rebaudioside C (6), rebaudioside C (7), rebaudioside D (8), and dulcoside A (9) using a condition closely associated with JECFA at temperatures $20^{\circ} \mathrm{C}, 40^{\circ} \mathrm{C}, 60^{\circ} \mathrm{C}$, and $79^{\circ} \mathrm{C}$. Using this method, the retention times of nine various steviol glycosides 1-9 (Figure 1) were identified at four temperatures $20^{\circ} \mathrm{C}, 40^{\circ} \mathrm{C}$, $60^{\circ} \mathrm{C}$, and $79^{\circ} \mathrm{C}$. Also, calculated the relative retention times for the steviol glycosides 2-9 against the standard steviol glycoside, rebaudioside A (1). Recently, there are several reports on the isolation, spectral analysis and analytical methods reported in the literature for the steviol glycosides isolated from S. rebaudiana [6]-[12].

\section{Experimental}

\subsection{Reagents and Chemicals}

Stevia glycoside standards kit containing dulcoside A, steviobioside, stevioside, rebaudioside A, rebaudioside B, rebaudioside C, rebaudioside D, rebaudioside F, rubososide was obtained from Chromadex (P/N KIT-00019568010, Irvine CA). HPLC grade acetonitrile and water were obtained from Fischer Scientific (Fair Lawn, NJ), and Pharm Co. (Brookfield, CT). Phosphoric acid (49\% - 51\%) HPLC grade was acquired from Sigma-Aldrich (Bellfonte, PA) whereas Sodium phosphate (monobasic) laboratory grade was obtained from Scientific Strategies (Oklahoma, OK).

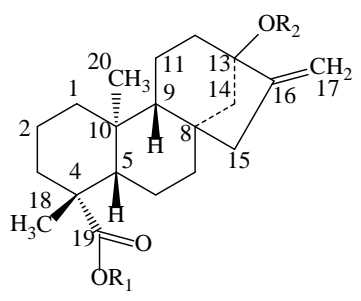

\begin{tabular}{|c|c|c|}
\hline Compound & $\mathbf{R}_{\mathbf{1}}$ & $\mathbf{R}_{\mathbf{2}}$ \\
\hline 1 & Glc $\beta 1$ & Glc $\beta 1-2($ Glc $\beta 1-3)$ Glc $\beta 1-$ \\
\hline 2 & $\mathrm{H}$ & Glc $\beta 1-2$ Glc $\beta 1$ \\
\hline 3 & Glc $\beta 1$ & Glc $\beta 1-2$ Glc $\beta 1$ \\
\hline 4 & Glc $\beta 1$ & Glc $\beta 1-$ \\
\hline 5 & $\mathrm{H}$ & Glc $\beta 1-2($ Glc $\beta 1-3)$ Glc $\beta 1$ \\
\hline 6 & Glc $\beta 1$ & Rha $\left.\alpha_{1-2(G l c} \beta 1-3\right) G_{c} \beta 1-$ \\
\hline 7 & Glc $\beta 1-2$ Glc $\beta 1-$ & Glc $\beta 1-2$ (Glc $\beta 1-3$ Glc $\beta 1-$ \\
\hline 8 & Glc $\beta 1$ & Xyl $\beta 1-2($ Glc $\beta 1-3)$ Glc $\beta 1-$ \\
\hline 9 & Glc $\beta 1$ & Rha $\alpha 1-2$ Glc $\beta 1-$ \\
\hline & \multicolumn{2}{|c|}{ Glc $\beta$ : D-Glucopyranosyl } \\
\hline & \multicolumn{2}{|c|}{ Rha $\alpha$ : L-Rhamnopyranosyl } \\
\hline & Xyl $\beta$ : D-Xylopy & \\
\hline
\end{tabular}

Figure 1. Structures of ent-13-hydroxykaur-16-en-19-oic acid glycosides (1-9). 


\subsection{Mobile Phase Preparation}

All solvents were degassed for at least fifteen minutes before use. The HPLC method employed was an isocratic binary solvent mobile phase system with a 32:68 mixture of acetonitrile and $10 \mathrm{mmol} / \mathrm{L}$ sodium phosphate buffer (pH: 2.63), very similar to the method reported in JECFA [5].

\subsection{Standard Preparation}

Each standard steviol glycoside 1-9 was prepared separately at a concentration of $10 \mathrm{mg} / \mathrm{ml}$. The dilutions for all steviol glycosides (1, 3-4, 6-9) were made using the phosphate buffer, but for steviolbiososide (2) and rebaudioside B (5) were prepared in methanol. Then the mixture of standard steviol glycosides 1-9 was prepared such that dilutions were made to set the concentration at $0.25 \mathrm{mg} / \mathrm{L}$ of each compound in the mixture.

\subsection{Instrumentation and Conditions}

An Agilent (Wilmington, DE) 1100 HPLC System, including a quaternary pump, a temperature controlled column compartment with additional 6 port switching valve, an auto sampler and VWD absorbance detector, was used for analysis. The detector was set-up at UV $210 \mathrm{~nm}$. The data acquisition was done using a Chemastation A 10.02 software. The column used for HPLC analysis was a reversed-phase C18 (2) 100 A Phenomenex (Torrance CA) (Length: $250 \mathrm{~mm}$, inner diameter $4.6 \mathrm{~mm}$, particle size: $5 \mu \mathrm{m}$ ); $\mathrm{pH}$ was measured using meter Metler Toledo seven compact pH/ion S220 (Switzerland). Branson Ultrasonic Cleaner Model 2510 (Maplewood, NJ) was used for degassing HPLC solvents.

\subsection{Analysis Procedure}

For the RP-HPLC method, the column was flushed with $50 \mathrm{~mL}$ of $90 \% \mathrm{MeCN}$ to waste before use and the samples were bracketed with standards by injecting them at the beginning and at the end of a run for accuracy of their retention times. $5 \mu \mathrm{L}$ of steviol glycoside mixture (1-9) has been injected at temperatures $20^{\circ} \mathrm{C}, 40^{\circ} \mathrm{C}, 60^{\circ} \mathrm{C}$, and $79^{\circ} \mathrm{C}$. All the nine steviol glycosides were detected under UV at $210 \mathrm{~nm}$. The two compounds rebaudioside A (1) and stevioside (3) were injected once at the beginning and once at the end of the sequence for consistency.

\section{Results and Discussion}

Generally separation of stevia sweeteners whose main difference from the chemical structural point of view is the number and type of glycoside moieties attached to aglycone moiety steviol, will be carried out using an amino $\left(\mathrm{NH}_{2}\right)$ column. Using this method, major steviol glycosides present in stevia extracts or purified steviol glycosides can be identified easily. Since water is a strong solvent for $\mathrm{NH}_{2}$ columns, a reversed-phase $\mathrm{C}_{18}$ column is generally preferred due to their superior reproducibility and durability. However, on a standard $\mathrm{C}_{18}$ column, some of the steviol glycosides elute at same retention times $\left(t_{R}\right)$, and with recently developed stationary phases addressed the limitations of the older bonded polar and bonded non-polar phase columns. Detection sensitivity was also a key factor considered in the development of HPLC method. In order to develop a suitable method for the separation of the glycosides, we have tested various conditions and found that although these are weak UV absorbers, they give an adequate signal at $210 \mathrm{~nm}$ to meet the required quantitation limit (LOQ) of 0.5 $\mathrm{mg} / \mathrm{L}$.

In this study, we have utilized an HPLC method with a reversed-phase column under isocratic binary solvent mobile phase system (32:68 mixture of acetonitrile and phosphate buffer) at temperatures $20^{\circ} \mathrm{C}, 40^{\circ} \mathrm{C}, 60^{\circ} \mathrm{C}$, and $79^{\circ} \mathrm{C}$. The $\mathrm{pH}$ of the buffer used in the HPLC method was at 2.63 and the injection volume of the standard steviol glycoside mixture was $5 \mu \mathrm{L}$. Duplicate runs were performed at each temperature and found almost identical results; hence one representative HPLC chromatogram for the mixture of steviol glycoside 1-9 at four different temperatures $20^{\circ} \mathrm{C}, 40^{\circ} \mathrm{C}, 60^{\circ} \mathrm{C}$, and $79^{\circ} \mathrm{C}$ is given in Figures 2-5.

The retention times for all the 9 naturally occurring steviol glycosides rebaudioside A (1), steviolbioside (2), stevioside (3), rubusoside (4), rebaudioside B (5), rebaudioside C (6), rebaudioside C (7), rebaudioside D (8), and dulcoside A (9) were identified and are given in Table 1 . A close observation of the retention times from the above Figures 2-5 and Table 1 indicated that better separation of steviol glycosides 1-9 was observed at higher temperatures. 


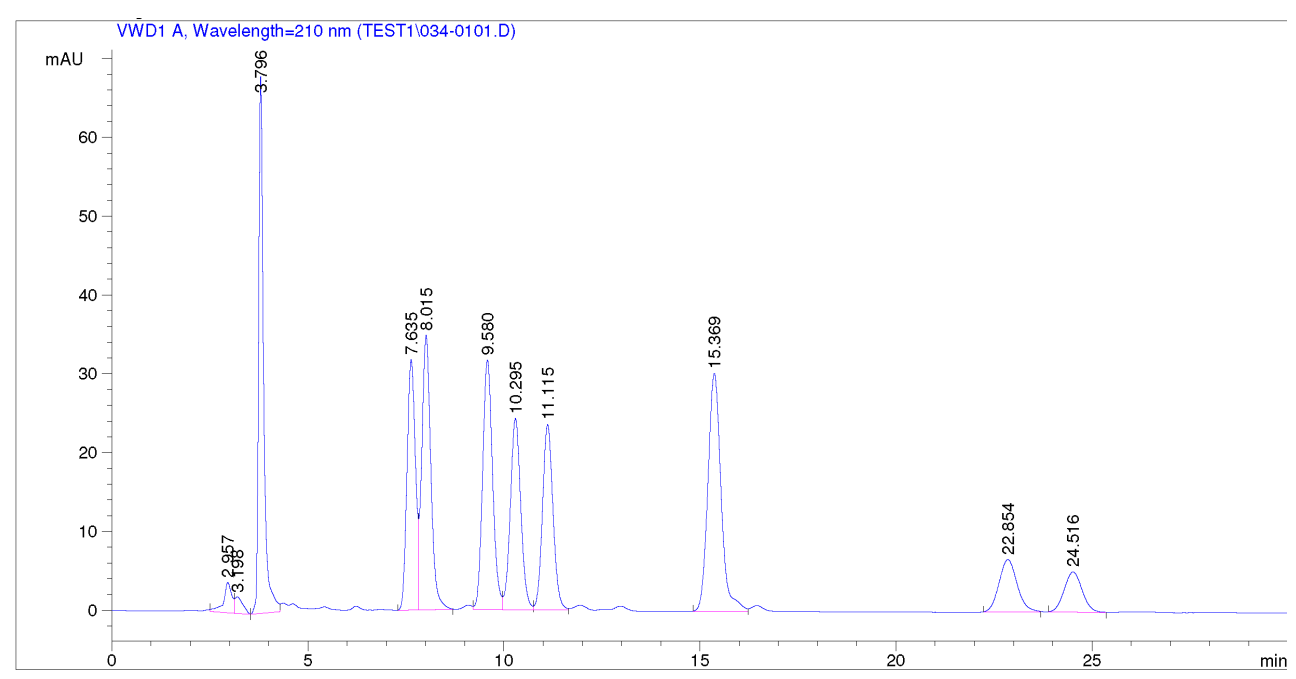

Figure 2. HPLC chromatogram for steviol glycosides 1-9 at $20^{\circ} \mathrm{C}$.



Figure 3. HPLC chromatogram for steviol glycosides $1-9$ at $40^{\circ} \mathrm{C}$.

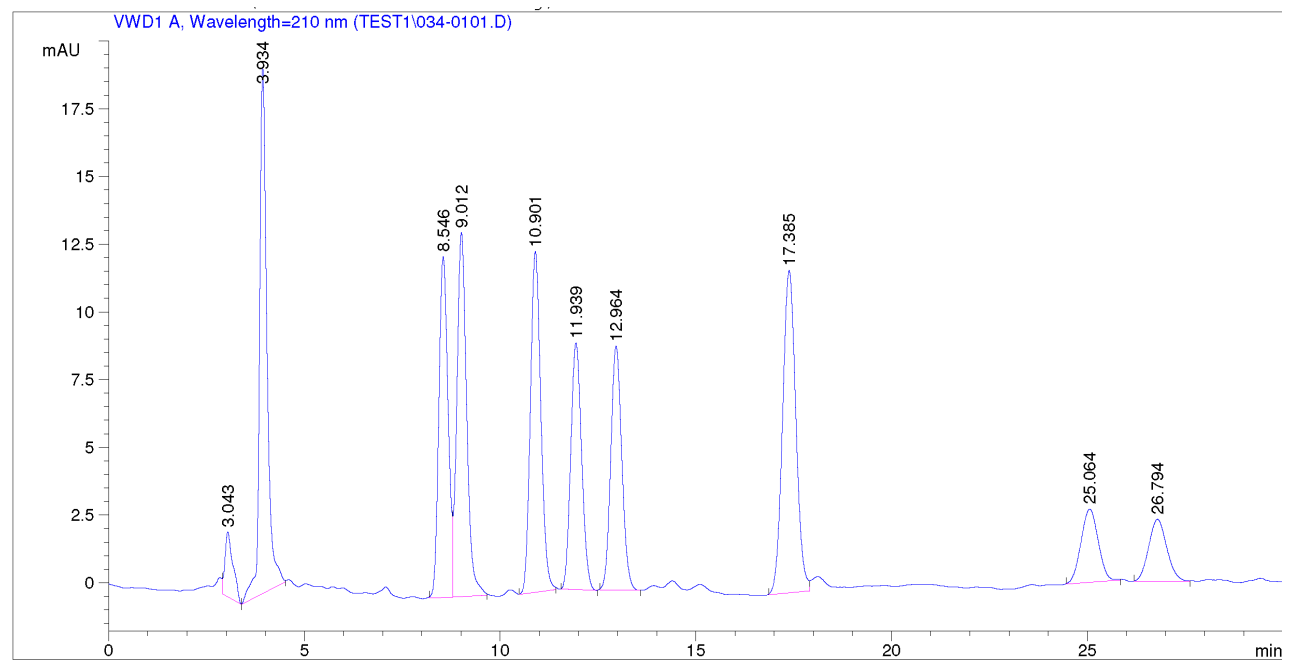

Figure 4. HPLC chromatogram for steviol glycosides 1-9 at $60^{\circ} \mathrm{C}$. 


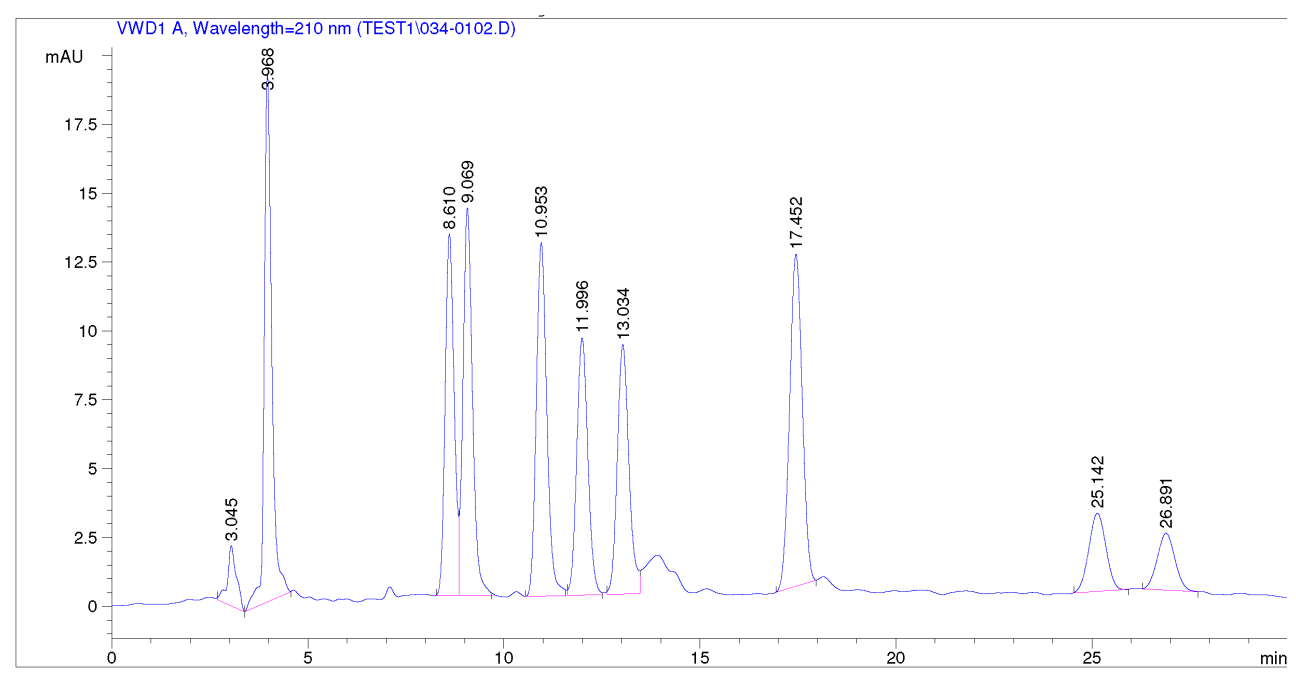

Figure 5. HPLC chromatogram for steviol glycosides $1-9$ at $79^{\circ} \mathrm{C}$.

Table 1. Retention $\left(t_{R}\right)$ times of steviol glycosides $1-9$ at temperatures $20^{\circ} \mathrm{C}, 40^{\circ} \mathrm{C}, 60^{\circ} \mathrm{C}$, and $79^{\circ} \mathrm{C}$.

\begin{tabular}{ccccccc}
\hline \multirow{2}{*}{ Compound } & Molecular Formula & Molecular Weight & \multicolumn{5}{c}{ Retention Times $\left(\boldsymbol{t}_{\boldsymbol{R}}\right.$, min) } \\
\cline { 4 - 7 } & & & $\mathbf{2 0}{ }^{\circ} \mathbf{C}$ & $\mathbf{4 0}^{\circ} \mathbf{C}$ & $\mathbf{6 0}^{\circ} \mathbf{C}$ & $\mathbf{7 9}^{\circ} \mathbf{C}$ \\
$\mathbf{1}$ & $\mathrm{C}_{44} \mathrm{H}_{70} \mathrm{O}_{23}$ & 966 & 7.635 & 8.740 & 8.546 & 8.610 \\
$\mathbf{2}$ & $\mathrm{C}_{32} \mathrm{H}_{50} \mathrm{O}_{13}$ & 642 & 24.516 & 25.509 & 26.794 & 26.891 \\
$\mathbf{3}$ & $\mathrm{C}_{38} \mathrm{H}_{60} \mathrm{O}_{18}$ & 804 & 8.015 & 9.246 & 9.012 & 9.069 \\
$\mathbf{4}$ & $\mathrm{C}_{32} \mathrm{H}_{50} \mathrm{O}_{13}$ & 642 & 15.369 & 17.380 & 17.385 & 17.452 \\
$\mathbf{5}$ & $\mathrm{C}_{38} \mathrm{H}_{60} \mathrm{O}_{18}$ & 804 & 22.854 & 23.787 & 25.064 & 25.142 \\
$\mathbf{6}$ & $\mathrm{C}_{44} \mathrm{H}_{70} \mathrm{O}_{22}$ & 950 & 10.295 & 12.322 & 11.939 & 11.996 \\
$\mathbf{7}$ & $\mathrm{C}_{50} \mathrm{H}_{80} \mathrm{O}_{28}$ & 1128 & 3.796 & 4.030 & 3.934 & 3.968 \\
$\mathbf{8}$ & $\mathrm{C}_{43} \mathrm{H}_{68} \mathrm{O}_{22}$ & 936 & 9.580 & 11.123 & 10.901 & 10.953 \\
$\mathbf{9}$ & $\mathrm{C}_{38} \mathrm{H}_{60} \mathrm{O}_{17}$ & 788 & 11.115 & 13.423 & 12.964 & 13.034 \\
\hline
\end{tabular}

The two major steviol glycosides of $S$. rebaudiana rebaudioside A (1) and stevioside (3) and the three minor compounds rebaudioside C (6), rebaudioside F (8), and dulcoside A (9) were having good separation at higher temperatures $40^{\circ} \mathrm{C}, 60^{\circ} \mathrm{C}$, and $79^{\circ} \mathrm{C}$. The other four minor steviol glycosides steviolbioside (2), rubusoside (4), rebaudioside $\mathrm{B}(5)$, and rebaudioside $\mathrm{C}$ (7), which were having retention times not close to the other five steviol glycosides separated well at all temperatures. From the above experiments it has been concluded that temperatures $40^{\circ} \mathrm{C}$ and $60^{\circ} \mathrm{C}$ would be ideal for steviol glycoside separation, whereas some degradation appeared at $79^{\circ} \mathrm{C}$. Currently, several other experiments are in progress to find out the best conditions to separate various steviol glycosides for their isolation using HPLC by changing the flow rate, $\mathrm{pH}$, as well as finding the best temperature between $40^{\circ} \mathrm{C}$ and $60^{\circ} \mathrm{C}$.

Also, the relative retention times for the steviol glycosides 2-9 were calculated against the major steviol glycoside, rebaudioside A (1) and are given in Table 2.

\section{Conclusion}

We are herewith reporting a qualitative HPLC method for the identification of nine steviol glycosides — rebaudioside A (1), steviolbioside (2), stevioside (3), rubusoside (4), rebaudioside B (5), rebaudioside C (6), rebaudioside C (7), rebaudioside D (8), and dulcoside A (9) based on the RP-HPLC method using UV detection system. Experimental results suggested that temperatures $40^{\circ} \mathrm{C}$ and $60^{\circ} \mathrm{C}$ would be ideal for steviol glycoside separation, whereas it was found that the steviol glycosides did not resolve clearly at $20^{\circ} \mathrm{C}$, and some degraded at $79^{\circ} \mathrm{C}$. 
Table 2. Relative retentions (RRT) of steviol glycosides 2-9 against rebaudioside A (1).

\begin{tabular}{ccccc}
\hline Compound & $\mathbf{R R T}$ at $\mathbf{2 0}{ }^{\circ} \mathbf{C}$ & $\mathbf{R R T}$ at $\mathbf{4 0}^{\circ} \mathbf{C}$ & $\mathbf{R R T}$ at $\mathbf{6 0}{ }^{\circ} \mathbf{C}$ & $\mathbf{R R T}^{\text {at }} \mathbf{7 9}{ }^{\circ} \mathbf{C}$ \\
\hline $\mathbf{1}$ & 1 & 1 & 1 & 1 \\
$\mathbf{2}$ & 3.211 & 2.91 & 3.135 & 3.123 \\
$\mathbf{3}$ & 1.049 & 1.057 & 1.054 & 1.053 \\
$\mathbf{4}$ & 2.012 & 1.988 & 2.034 & 2.026 \\
$\mathbf{5}$ & 2.993 & 2.721 & 2.932 & 2.920 \\
$\mathbf{6}$ & 1.348 & 1.409 & 1.397 & 1.393 \\
$\mathbf{7}$ & 0.497 & 0.461 & 0.460 & 0.460 \\
$\mathbf{8}$ & 1.254 & 1.272 & 1.275 & 1.272 \\
$\mathbf{9}$ & 1.455 & 1.535 & 1.516 & 1.513 \\
\hline
\end{tabular}

\section{Acknowledgements}

We thank James May, Chief Executive Officer and Carol May, President of Wisdom Natural Brands for their support.

\section{References}

[1] Mosettig, S.E. and Nes, W.R. (1955) Stevioside. II. The Structure of the Aglucon. Journal of Organic Chemistry, 20, 884-899. http://dx.doi.org/10.1021/jo01125a013

[2] Mosettig, S.E., Beglinger, U., Dolder, F., Lichiti, H., Quitt, P. and Waters, J.A. (1963) The Absolute Configuration of Steviol and Isosteviol. Journal of American Chemical Society, 85, 2305-2309. http://dx.doi.org/10.1021/ja00898a025

[3] Brandle, J.E., Starrratt, A.N. and Gijen, M. (1998) Stevia rebaudiana: Its Agricultural, Biological and Chemical Properties. Canadian Journal of Plant Sciences, 78, 527-536. http://dx.doi.org/10.4141/P97-114

[4] Wayne, E.S. and Lin, L. (2009) NMR Studies of the Conformation of the Natural Sweetener Rebaudioside A. Carbohydrate Research, 344, 2533-2538. http://dx.doi.org/10.1016/j.carres.2009.10.005

[5] JECFA (2010) Steviol glycosides [Prepared at the 73rd JECFA (2010) and Published in FAO JECFA Monographs 10 (2010)]. In: Combined Compendium of Food Additive Specifications (Online Edition). General Specifications for Enzymes Analytical Methods, Volume 4, (FAO JECFA Monographs 10), Food and Agriculture Organization of the United Nations (FAO), Joint FAO/WHO Expert Committee on Food Additives (JECFA), Rome. http://www.fao.org/ag/agn/jecfa-additives/specs/monograph10/additive-442-m10.pdf

[6] Ahmed, M.S. and Dobberstein, R.H. (1982) Stevia rebaudiana. III. High-Performance Liquid Chromatographic Separation and Quantitation of Rebaudiosides B, D, and E, Dulcoside A, and Steviolbioside. Journal of Chromatography (A), 245, 373-376. http://dx.doi.org/10.1016/S0021-9673(00)88027-9

[7] Kolb, N., Herrera, J.L., Ferreyra, D.J. and Uliana, R.F. (2001) Analysis of Sweet Diterpene Glycosides from Stevia rebaudiana: Improved HPLC Method. Journal of Agricultural and Food Chemistry, 49, 4538-4541. http://dx.doi.org/10.1021/jf010475p

[8] Chaturvedula, V.S.P., Mubarak, C. and Prakash, I. (2012) IR Spectral Analysis of Diterpene Glycosides of Stevia rebaudiana. Food and Nutrition Sciences, 3, 1467-1471. http://dx.doi.org/10.4236/fns.2012.310191

[9] Chaturvedula, V.S.P., Chen, S., Yu, O. and Mao, G. (2013) NMR Spectral Analysis and Hydrolysis Studies of Rebaudioside N, a Minor Steviol Glycoside of Stevia rebaudiana Bertoni. Food and Nutrition Sciences, 4, 1004-1008. http://dx.doi.org/10.4236/fns.2013.410130

[10] Chaturvedula, V.S.P. and Prakash, I. (2011) A New Diterpenoid Glycoside from Stevia rebaudiana. Molecules, 16, 2937-2943. http://dx.doi.org/10.3390/molecules16042937

[11] Chaturvedula, V.S.P. and Prakash, I. (2011) Structures of the Novel Diterpene Glycosides from Stevia rebaudiana. Carbohydrate Research, 346, 1057-1060. http://dx.doi.org/10.1016/j.carres.2011.03.025

[12] Chaturvedula, V.S.P. and Prakash, I. (2011) Additional Minor Diterpene Glycosides from Stevia rebaudiana. Natural Product Communications, 6, 1059-1062. 
Scientific Research Publishing (SCIRP) is one of the largest Open Access journal publishers. It is currently publishing more than 200 open access, online, peer-reviewed journals covering a wide range of academic disciplines. SCIRP serves the worldwide academic communities and contributes to the progress and application of science with its publication.

Other selected journals from SCIRP are listed as below. Submit your manuscript to us via either submit@scirp.org or Online Submission Portal.
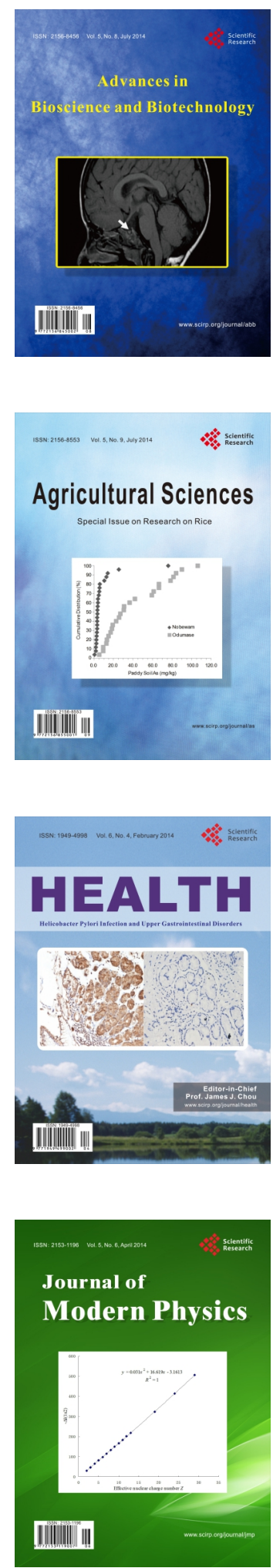
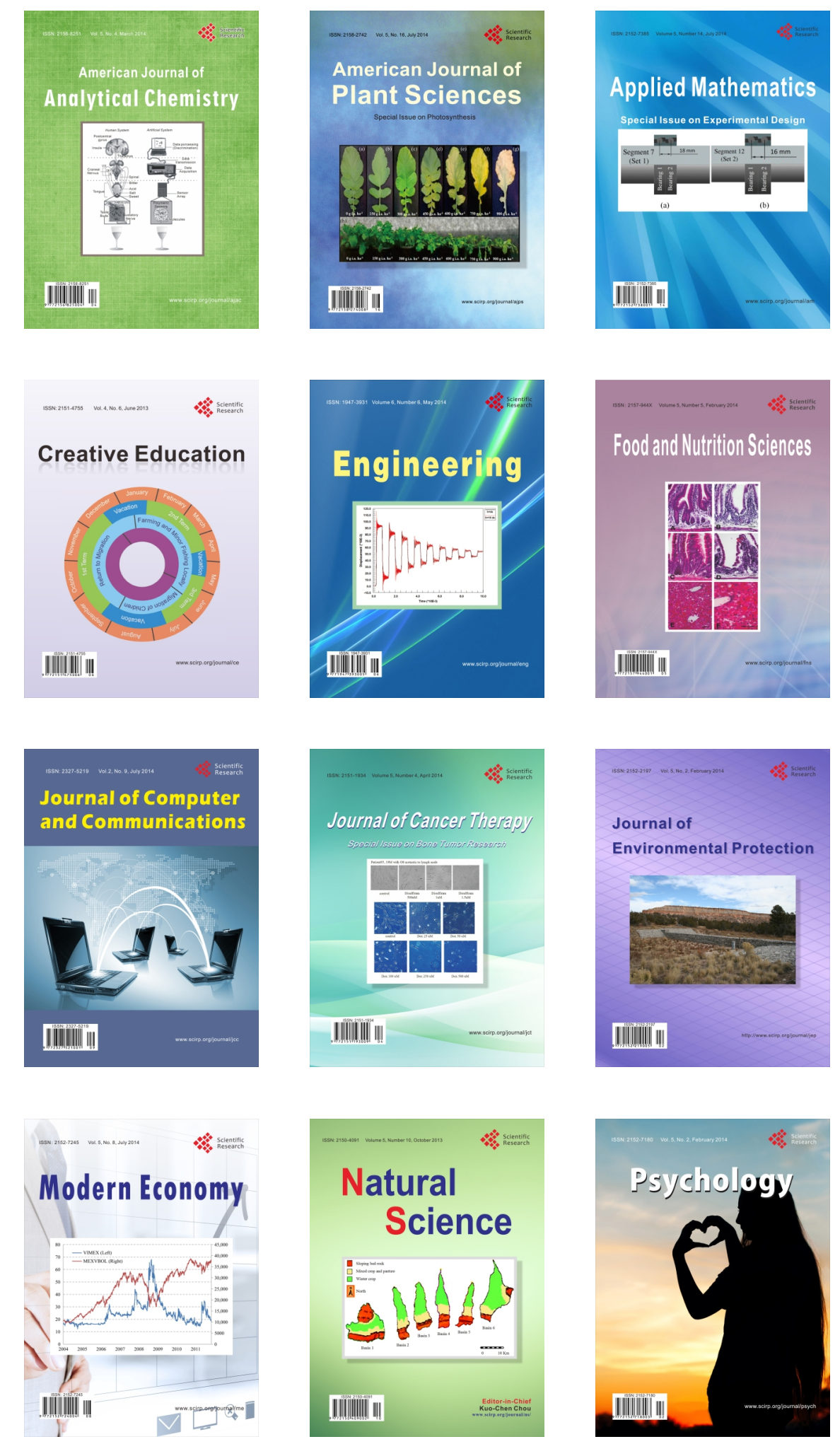